\title{
HUKUM PERBANKAN SYARIAH DI INDONESIA
}

\author{
Arniyati \\ Fakultas Ekonomi dan Bisnis Islam Universitas Islam Negeri Makassar \\ arniansary@gmail.com
}

\begin{abstract}
Abstrak
Bank Syariah adalah lembaga finansial yang memiliki (risalah) dan metholog manhajy yang esklusif akan kerangka syariah terkaid kaidah-kaidahnya yang bersumber dari etika dan nilai-nilai syariat Islam yang komprehensif dan universal.Aspek Hukum Undang-undang Perbankan Syariah UU No. 21 Tahun 2008, dilihat dari sisi filosofi yuridis dan Sosiologis pada dasarnya telah menjawab kebutuhan rasa Keadilan Ummat Islam sebagai konsekuensi fluralisme hukum yang hidup dan tumbuh dalam dinamika masyarakat Indonesia. Sedangkan dari pendekatan yuridis formalistik melalui payung hukum UU No.3 tahun 2006 dan UU No.4 tahun 2004 implementasinya menuntut hakim dalam mewujudkan dan menegakkan keadilan, hendaknya mengetahui dan memahami aspirasi serta nilai-nilai yang hidup dalam masyarakat dan orientasi, keadilanlah yang harus dikedepankan bersama-sama dengan orientasi kepastian hukum dan kemanfaatan
\end{abstract}

\section{PENDAHULUAN}

Perbankan merupakan lembaga keuangan yang sangat berperan penting bagi pembagunan suatu negara. Dengan kata lain perbankan merupakan salah satu agen pembangunan ( agent of development). hal ini di sebabkan karena fungsi perbankan adalah sebagai lembaga intermediasi keuangan (financial intermediary institution) sebagai ditegaskan dalam pasal 1angka 2 Undang-Undang Nomor 7 tahun 1992 yakni bahwa Bank adalah badan usaha yang menghimpun dana 
dari masyarakat dalam bentuk simpanan dan menyalurkannya kepada masyarakat dalam bentuk kredit dan at dalam bentuk lainnyadalam rangka meningkatkan taraf hidup rakyat banyak. Di sisi lain umat Islam sebagian besar masih belum dapat menerima bank, bukan karena tidak percaya akan arti pentingnya Bank bagi pembangunan akan tetapi karena Bank-Bank dimaksud mendasarkan pada sistem bunga (interenst based). bunga oleh sebagian besar umat Islam dianggap riba yang secara jelas dan tegas dilarang oleh ajaran islam sebagaimana tertuang dalam al-qur'andan Hadis Nabi Muhammad SAW.

Perbankan yang merupakan salah satu pilar ekonomi merupakan perwujudan dari nilai Islam terutama pada wilayah "muamalah-syariah al Umumiyyah", dimana persoalan ekonomi berada pada ranah publik, manusia diberikan kebebasan untuk menyusun konsep, mengatur dan menjalankan sendiri sepanjang tidak bertentangan dengan ketentuan syariat Islam. Rasul bersabda "Antum a'lamu bi ummuriddunyakum" (kamu lebih mengetahui urusan duniamu). Firman Allah SWT: "Sesungguhnya usaha manusia itu macam-macam" (QS. Al-Lail: 595).

Indonesia sejak tahun 1992 telah mulai berdiri perbankan syariah yang dipelopori BMI (Bank Muamalat Indonesia), selanjutnya ber kembang dengan pesat tahun 2009 telah berdiri 1440 kantor Bank 
Syariah, belum termasuk bank konvensional yang membuka unit usaha syariah.3 Karakteristik sistem perbankan Islam yang beroperasai berdasarkan prinsip bagi hasil (mudharabah) diharapkan mampu memberikan alternatif sistem perbankan yang saling menguntungkan bagi masyarakat dan bank, serta menonjolkan aspek keadilan dalam bertransaksi, investasi yang beretika, mengedepankan nilai-nilai kebersamaan, persaudaraan dalam berproduksi dan menghindari kegiatan spekulatif dalam bertransaksi keuangan. Dengan menyediakan beragam produk serta layanan jasa perbankan yang beragam diharapkan perban kan syariah menjadi alternatif sistem perban kan yang kredibel dan dapat diminati oleh se luruh golongan masyarakat Indonesia tanpa kecuali.

Lembaga perbankan di zaman modern ini sepertinya tidak bisa lagi dipisahkan dari roda ekonomi manusia. Perbankan adalah salah satu kegiatan usaha yang paling dominan dan sangat dibutuhkan di dunia ekonomi dewasa ini. Karena fungsinya sebagai pengumpul dana yang sangat berperan demi menunjang pertumbuhan ekonomi. Sebagai pengumpul dana, lembaga perbankan mampu ikut serta membantu pembangunan dengan menyalurkan dananya untuk proyek-proyek pemerintah.5 Lembaga perbankan juga menyediakan dana bagi pengusaha-pengusaha swasta untuk mendanai usaha mereka, bahkan lembaga perbankan juga berperan penting dalam 
perkembangan usaha kecil dan menengah dengan penyaluran dana bagi mereka.

\section{PEMBAHASAN}

A. Perbankan Syariah

Bank berasal dari kata Italia bancoyang artinya bangku. Bangku inilah yang dipergunakan oleh bankir untuk melayani kegiatan operasionalnya kepada para nasabah. Istilah bangku secara resmi dan populer menjadi bank. Bank termasuk perusahaan industri jasa karena produknya hanya memberikan pelayanan jasa kepadaa masyarakat. Secara sederhana bank dapat diarstikan sebagai lembaga keuangan yang kegiatan usahanya adalah menghimpun dana dari masyarakat dan menyalurkan kembali dana tersebut kemasyarakat serta memberikan jasa-jasa bank lainnya. (Nurul Ichsan Hasan, 2014, hlm. 3)

Secara umum pengertian Bank Syariah adalah Bank yang pengoperasiannya di sesuaikan dengan prisnip syariat Islam. Ada banyak istilah diberikan untuk menyebut entitas Bank Syariah selain, yakni Bank tanpa bunga, Bank tanpa riba, dan Bank syariah. Yang secara lengkap disebut "Bank Berdasarkan Prinsip Syariah". lembaga ini dalam operasional dan produknya dikembangkan berlandaskan al-qur'an dan hadis nabi Muhammad SAW.

Bank syariah adalah Bank yang menjalankan kegiatan usahanya berdasarkan prinsip sayriah dan menurut jenisnya terdiri atas Bank umum 
Syariah (BUS) dan Bank pembiayaan Rakyat Syariah (BPRS). sedangkan prinsip syariah adalah prinsip hukum islam dalam kegiatan perbankan berdasarkan fatwa yang dikeluarkan oleh lembaga yang kewenangannya dalam penetapan fatwa dibidang syariah.

Berdasarkan ketentuan pasal 34 Undang-Undang Bank Indonesia terdapat pembagian tugas dalam melaksanakan pengawasan perbankan, yaitu tugas mengatur bank dilaksanakan oleh Bank Indonesia, sementara tugas mengawasi Bank dilaksanakan oleh LPJ ((Zulfi Diane Zaini,2021:158). Apabila dilihat dari sistematika Undang Undang Bank Indonesia pasal 34 Undang-Undang Bank Indonesia berada dalam lingkup Bab VI yakni tentang tugas mengatur dan mengawasi Bank, sementara linkup LPJK tidak hanya dibatasi untuk melakukan pengawasan terhadap Bank, akan tetapi juga pengawasan terhadap badan lain yang bukan merupakan kewenngan Bank Indonesia seperti asuransi dana pensiun, sekuritas, model ventura, perusahaan pembiayaan, serta badan-badan hukum lain yang menyelenggarakan pengelolaan dana Masyarakat.

Dalam kamus istilah hukum Fockema Andreae yang mengatakan bahwa bank adalah suatu lembaga atau orang pribadi yang menjalankan perusahaan dalam menerima dan memberikan uang dari dan kepada pihak ketiga. (Hermansyah, 2005, hlm. 8). Dengan kata lain bank sebagai 
Financial Intermediary dengan usaha utama menghimpun dan menyalurkan dana masyarakat serta memberikan jasa-jasa lainnya dalam lalu lintas pembayaran. Masyarakat kini telah ramai menggunakan jasa bank untuk segala kepentingan salah satunya adalah mempermudah tansaksi pembayaran.

Menurut Pasal 1 ayat (2) UU Perbankan Bank adalah Badan Usaha yang menghimpun dana dari masyarakat dalam bentuk simpanan dan penyalurannya kepada masyarakat dalam bentuk kredit dan/atau bentuk-bentuk lainnya dalam rangka meningkatkan taraf hidup rakyat banyak.

Pasal 1 ayat (1) Undang-Undang Perbankan: Perbankan adalah segala sesuatu yang menyangkut Bank, mencakup kelembagaan, kegiatan usaha, serta cara dan proses dalam melaksanakan kegiatan usahanya. yang dimaksud dengan bank adalah Badan Usaha yangmenghimpun dana dari masyarakat dalam bentuk simpanan dan menyalurkannya kepada masyarakat dalam bentuk kredit dan/atau bentuk-bentuk lainnya dalam rangka meningkatkan taraf hidup orang banyak. Bank berfungsi sebagai Financial Intermediary dengan usaha utama menghimpun dan menyalurkan dana masyarakat serta memberikan jasa-jasa lainnya dalam lalu lintas pembayaran. 
Dalam Undang-undang Perbankan Indonesia, yakni Undang-undang No. 7 Tahun 1992 tentang Perbankan sebagaimana telah diubah dengan Undang-undang No. 10 Tahun 1998, membedakan bank berdasarkan kegiatan usahanya menjadi dua, yaitu bank yang melaksanakan kegiatan usaha secara konvensional dan bank yang melaksanakan kegiatan usaha berdasarkan prinsip syariah. Sebagaimana disebutkan dalam butir 13 Pasal 1 UUPI memberikan batasan pengertian prinsip syariah sebagai aturan perjanjian berdasarkan hukum Islam antara Bank dan pihak lain untuk penyimpanan dana dan/atau pembiayaan kegiatan usaha, atau kegiatan lainnya yang dinyatakan sesuai dengan Syariah, antara lain, pembiayaan berdasarkan prinsip bagi hasil (mudharabah), pembiayaan berdasarkan prinsip penyertaan modal (musyarakah), prinsip jual beli barang dengan memperoleh keuntungan (murabahah), atau pembiayaan barang modal berdasarkan prinsip sewa murni tanpa pilihan (ijarah), atau dengan adanya pilihan pemindahan kepemilikan atas barang yang disewa dari pihak Bank oleh pihak lain (ijarah wa iqtina).

Di bidang perbankan Indonesia telah mengambil kebijaksanaan dengan merubah dan menyempurnakan pasal-pasal ari Undang-Undang No.7 tahun 1992 dengan mengundangkan Undang-Undang N.10 Tahun 1998 tentang perubahan atas Undang-Undang No.7 Tahun 1992. 
perubahan dan peyempurnaan lewat Undang-Undang No.10/1998 ini cukup pula menyulitkan.

1. Azaz perbankan indonesia adalah demokrasi ekonomi dengan prinsip kehati-hatian. Fungsi utamanya sebagai penghimpun dan penyalur dana masyarakat. Tujuan perbankan adalah menunjang pembangunan nasioanl dalam rangka meningkatkan pemerataan, pertumbuhan ekonomi dan stabilitas nasional ke arah peningkatan kesejahteraan rakyat banyak.

2. Fungsi utama perbankan indonesia adalah sebagai penghimpun dan penyalur dana masyarakat.

3. Sedangkan tujuannya menunjang pelaksanaan pembangunan nasioanl dalam rangka meningkatkan pemerataan pertumbuhan ekonomi dan stabilitas nasional ke arah peningkatan kesejahteraan rakyat banyak.

4. Ketentuan-ketentuan umum perbankan indonesia (termasuk peristilahan resmi mengenai perbankan).

Maka pasal 1 Undang-Undang No.7/1992 di ubah dan di sempurnakan oleh Undang-Undang No.10/1998. pasal 1 Undang-Undang No.1/1998, merumuskan:

- Perbankan adalagh segala sesuatu yang menyangkut tentang Bank, mencakup kelembagaan, kegiataan usaha serta cara dan proses dalam melaksanakan kegiatan usahanya. 
- Bank adalah badan usaha yang menghimpun dana dari masyarakat dalam bentuk simpanan dan menyalurkannya kepada masyarakat dalam bentuk kredit dan atau bentuk-bentuk lainnya dalam rangka meningkatkan taraf hidup rakyat banyak.

- Bank umum adalah Bank yang melaksanakan usaha secara konvensional dan/atau berdasarkan prinsip syariah yang dalam kegiatannya memberikan jasa dalam lalu lintas pembayaran.

- Bank Perkreditan Rakyat adalah bank yang melaksanakan kegiatan usaha secara konvensional atau berdasarkan prinsip syariah yang dalam kegiatannya tidak memberikan jasa dalam lalu lintas pembayaran.

- Simpanan adalah dana yang dipercayakan oleh masyarakat kepada bank berdasarkan perjanjian penyimpanan dana dalam bentuk giro, deposito, tabungan dan atau bentuk lainnya yang dipersamakan dengan itu.

- Giro adalah simpanan yangpenarikannya dapat dilakukan setiap saat dengan menggunakan cek, bilyet giro, sarana perintah pembayaran lainnya, atau dengan pemindahbukuan. 


\section{PENUTUP}

Berdasarkan uraian di atas dapat diperoleh kesimpulan, sebagai berikut:

Semakin tahun Bank Syariah mulai berkembang pesat di kalangan masyarakat perkembangannya yang mulai merabah dan Perbankan yang merupakan salah satu pilar ekonomi merupakan perwujudan dari nilai Islam terutama pada wilayah. berdasarkan prinsip bagi hasil (mudharabah) diharapkan mampu memberikan alternatif sistem perbankan yang saling menguntungkan bagi masyarakat dan bank, serta menonjolkan aspek keadilan dalam bertransaksi, investasi yang beretika, mengedepankan nilai-nilai kebersamaan, persaudaraan dalam berproduksi dan menghindari kegiatan spekulatif dalam bertransaksi keuangan. 


\section{DAFTAR PUSTAKA}

Akram, Andi. "Sejarah Peradilan Agama di Indo nesia". Al Manahij. Vol.

2 No. 1. Janu ari-Juni 2008;

Abdullah Abdul Husain al-Tariqi, Ekonomi Islam Prinsip Dasar dan Tujuan,terjemah:

Abdullah Abdul Husain Taliq, Ekonomi Prinsip Dasar dan Tujuan Terjemah: Irfan showani, cet. Pertama (yogyakarta: Magistra Insania Press:2004)

Irfan Showani, cet. Pertama (Yogyakarta: Magistra Insania Press: 2004)

Hasanuddin Rahman, Aspek Hukum Pemberian Kredit Perbankan Indonesia, PT.Citra

Aditya Bakti, Bandung 1998

Nafis, M Cholil, Teori Hukum Ekonomi Syariah, (Jakarta: UI Press, 2011)

Dr, Ir. Martono Anggusti, SH.,MM.,M.Hum Dasar-Dasar Pasar Modal

C. Parthasarathy. Chariman of Karvy Consultants. Jakarta,2011

Kampus B Universitas Bandar Lampung Jl. Z.A Pagar Alam No.89 Labuhan Ratu,

Bandar Lampung 35142

Mandar Maju/2003/Bandung 